\title{
IAMJ
}

INTERNATIONAL

AYURVEDIC

MEDICAL JOURNAL

Research Article

ISSN: 23205091

Impact Factor: 5.344

\section{A COMPARATIVE CLINICAL STUDY ON THE EFFECTIVENESS OF UDVARTANA WITH SIRAVYADHA IN THE MANAGEMENT OF SIRAJAGRANTHI (VARICOSE VEIN)}

\author{
Neethu Dev ${ }^{1}$, Santosh Kumar $\mathbf{J}^{2}$, SubhashRai $\mathbf{N}^{3}$ \\ ${ }^{1}$ PG Scholar, Department of PG Studies in Shalya Tantra, Karnataka Ayurveda Medical College, Mangalore, \\ Karnataka, India \\ ${ }^{2}$ Professor; Department of PG Studies in Shalya Tantra, Karnataka Ayurveda Medical College, Mangalore, \\ Karnataka, India \\ ${ }^{3}$ Professor; Department of PG Studies in Shalya Tantra, Karnataka Ayurveda Medical College, Mangalore, \\ Karnataka, India
}

Corresponding Author: neethudev90@gmail.com

\section{https://doi.org/10.46607/iamj1 108112020}

(Published online: November 2020)

Open Access

(C) International Ayurvedic Medical Journal, India 2020

Article Received: 30/10/2020 - Peer Reviewed: 08/11/2020 - Accepted for Publication: 10/11/2020

Check for updates

\begin{abstract}
Varicose vein of the lower limbs is one of such clinical condition that hampers the beauty of the legs. It is a very common condition, affecting up to three in 10 adults. Varicose veins affect up to $25 \%$ of women and $15 \%$ of men. By the age of 50 , nearly $40 \%$ of women and $20 \%$ of men have significant vascular problems. The lifestyle changes, obesity, occupational pattern of prolonged standing and pregnancy are considered to be significantly contributing to this situation. Siravyadha, which is one among the types of Sasastra Raktamokashana is mentioned in the treatment of Sirajagranthi in our classics. It is considered as Ardha Chikitsa of Shalyatantra and is said to provide immediate results. Udvartana which is having Vatakaphahara Twakprasadana and Siramukhavivechana property is said to be effective in Sirajagranthi. Also, the procedure is done in Pratiloma (upward) direction which results in Dridikarana of angas by toning them and relieves the symptoms of varicose vein. Hence an effort was made to evaluate the effect of Siravyadha by Vrihimukha Sastra and Udvartana with Kolakulathadi Churna in the management of Sirajagranthi (varicose vein), this study was planned with the following aims. Objective: A detailed
\end{abstract}


study on Sirajagranthi and its Management. To study the effect of Udvartana with Siravyadha in Sirajagranthi (varicose veins). To study the effect of Siravyadha in Sirajagranthi (varicose veins)., To compare the efficacy of both in Sirajagranthi (varicose veins). Method: The outcome of the study is evaluated clinically on a minimum of 60 patients with Sirajagranthi, divides 2 groups A and B. Group A received Udvartana for 7days and then Siravyadha on $8^{\text {th }}$ day. Group B received Siravyadha for 1 day and followed by Pathya for 7days. The duration of study was 28days in both the groups and observations were made on before and after the treatment $\left(0^{\text {th }}, 8^{\text {th }}\right.$ and $28^{\text {th }}$ day). Data obtained was statistically analysed and interpreted. Results: The results were assessed based on the relief obtained to the subjective and objective parameters and was taken for consideration for the study and were found statistically significant on all the parameters $(\mathrm{p}<0.05)$. Conclusion: From the study it is evident that effectiveness of Udvartana along with Siravyadha is more significant in reducing the signs and symptoms of Sirajagranthi.

Keywords: Sirajagranthi, Udvartana, Siravyadhaetc.

\section{INTRODUCTION}

The science of life, Ayurveda has mentioned various principles for the wellbeing of living beings. The main aim of Ayurveda is to maintain the health and cure the disease. Thus, it can be seen in both maintenance of health and curing of diseased is given equal importance. Healthy body and a healthy mind make man a master in the art of happy living.

Today man is totally involved in achieving high standards of living to achieve a good pleasant life and as competition exist in every field; one has to work very hard beyond his physical capacity and mental limits of power. All these things affect inversely the health of the people. Today, a lot of occupation and professions have sprung up where a person is required to either constantly stand up for a long time or made to sit with legs hanging down for a considerable time.

Varicose vein one of the commonest diseases in surgical practice. It occurs in people who are habitual to standing for long periods. It is a very common condition, affecting up to three in 10 adults ${ }^{[1]}$. Varicose veins affect up to $25 \%$ of women and $15 \%$ of men. By the age of 50 , nearly $60 \%$ of women and $20 \%$ of men have significant vascular problems ${ }^{[2]}$. The lifestyle changes, obesity, occupational pattern of prolonged standing and pregnancy are considered to be significantly contributing to this situation ${ }^{[3]}$.

Abnormally dilated elongated and tortuous alteration in the saphenous veins and their tributaries is called as varicose vein. Varicose veins of the lower limbs are the penalty the human being has to pay for its erect posture ${ }^{[3]}$. Its main reasons are hereditary factors, prolonged standing, heavy weightlifting, multiple pregnancies, high blood pressure and obesity. It may later lead to complications like pigmentation, ankle flare, itching over the varicosities, eczema, ulceration etc ${ }^{[3]}$. People rarely consider this condition unless complications like these arises, which makes the treatment a challenge to the doctors. Attending this condition in early stages either as a part of beauty concern or otherwise gives more scope for early treatment or to prevent the development of skin changes and other complications.

Sirajagranthi $i^{[4,5,6]}$ which can be co-related to varicose vein is described as due to Vataprakopaka Nidanas like physical exertion and straining, Vayu enters the Sira causing Sampeedana, Sankocha and Vishoshana and produce Granthi formation in Sira which is nonpulsating and painless. Siragatavata ${ }^{6]}$ produces Shoola, Akunchana and Purana of Sira.

Rakthamokshana is the treatment of choice prescribed by the classics for Sirajagranthi $i^{[6]}$ along with Sneha, Abhyanga, Upanaha, Mardhana and Alepana. Siravyadha, which is one among the types of Sasastra Raktamokashana is mentioned in the treatment of Sirajagranthi in our classics. It is considered as Ardha Chikitsa of Shalya Tantra and with Siravyadha 'the diseases perish by root, just as when the water bunds are removed, the rice and other crops are destroyed ${ }^{[7] .}$ Among the different techniques for Siravyadha, Vri- 
himukha Shastra is indicated in muscular or fleshy areas and Kutharika Shastra for puncturing veins on the bones ${ }^{6}$. Here Vrihimukha Shastra is taken for the study. Udvartana is a procedure of applying powders of herbs to the skin and rubbing it to form wicks with gentle strokes directing towards heart, with the palm evenly spread on the surface of the skin. While understanding the process of 'Udvartana' through the Samhita, it is observed that there are various words used to explain the meaning of 'Udvartana'. It helps to maintain Prakrutatva of Vayu by pacifying increased or vitiated Vayu. It decreases the fat and Vikruta Kapha. It cleans and provides smoothness to the skin and firmness to the body. Udvartana ${ }^{[8]}$ which is having Vatakaphahara Twakprasadana and Siramukhavivechana property is said to be effective in Sirajagranthi. Also, the procedure is done in Pratiloma (upward) direction which results in Dridikarana of Angas by toning them and relieves the symptoms of varicose vein.

So, in the present study, an effort was made to explore the effect of Siravyadha by Vrihimukha Sastra and Udvartana with Kolakulathadi Churna in the management of Sirajagranthi (varicose vein).

\section{Materials and Methods:}

\section{a. Source of Data:}

1 Literary source: All the classical, modern literatures and contemporary texts including the websites about the disease and the drug was reviewed and documented in the present study.

2 Drug source: Raw drugs required were identified ane selected from the local market and the preparation Udvartana Choorna was done in the Karnataka Ayurved Medical college hospital.

3 Sample source:60 patients diagnosed as Sirajagranthi were selected and were grouped into two Groups A\& B irrespective of their age, sex, religion, socio economic status etc. Each patient was selected for the trial after voluntary consent.

\section{b. Method of collection of data:}

Sample size:60 patients diagnosed as Sirajagranthi were divided into two equal groups- Group A and Group B for the study.

Study design: Comparative clinical study.

Selection Criteria: The cases were selected strictly as per the pre-set inclusion and exclusion criteria. c. Diagnostic criteria

$>$ Clinical features of Sirajagranthi (varicose vein) viz. Sampeedana, Samkochana and Vishoshanam of Siras (dilated, elongated and tortuous veins) will be taken as the criteria for diagnosis.

$>$ Brodie -Trendelenburg test

$>$ Multiple Tourniquet test

$>$ Perthes test

$>$ Modified Perthes test

d. Inclusion criteria

$>$ Patient aged between 20-60 years of either sex.

$>$ Patient suffering from Primary and secondary varicose vein.

$>$ Patient with Sirajagranthi (Varicose vein) in lower limb only.

$>$ Patient indicated for Siravyadha and Udvartana.

e. Exclusion criteria

$>$ Patient with Chronic systemic diseases.

$>$ Patient with coagulopathy or bleeding diseases.

$>$ Varicosity associated with complications like deep veinthrombosis, calcification, equines deformity, venous ulcer.

$>$ Siravyadha Anarhas \& Udvartana Anarhas

f. Investigations: Following lab investigations will be performed for the diagnosis and to rule out major pathological conditions:

$>\mathrm{Hb} \%$

$>$ Blood sugar
Any other investigations if necessary.

\section{Materials and methods:}

- Snigdha Yavagu, Moorchita Tilathaila, Nadee SwedanaYantra, Vrihimukha Sastra, adhesive plaster, kidney tray, antiseptic lotion, Bandaging role, Distilled water and Measuring glass

- Kolakulathadi Churna

Design of study:

Group- A: 30 patients was managed with Udvartana with Kolakulathadi for 7days followed by Siravyadha on $8^{\text {th }}$ day

Drugs Required: Kolakulathadi Churna

Site: lower limbs 
Period: 7days

Procedure

\section{Poorva Karma}

\section{Preparation of the Medicine:}

The material and medicines needed for the treatment were collected beforehand.

\section{Preparation of the Patient:}

The patient was thoroughly examined and the Prakruthi, Vikruti were documented in detail.

\section{Pradhana Karma:}

Patient was asked to lie down on the massage table comforta which Siravyadha was meant to be done.

bly. Udvartana to be done simultaneously and synchronouslypradhana Karma: Tourniquet was above the site of done on both the side of lower extremities in prone position over the period of 20 minutes.

\section{Paschat Karma}

After the procedure wiped off the medicament on the body. Patient was adviced to take warm water bath and follow the Pathya and Apathya

Siravyadhawas done on 30 patients of Group A after Udvartana.

\section{Materials Required:}

Snigdha Yavagu, Moorchita Tila Thaila, Nadee Swedana Yantra, Vrihimukha Sastra, adhesive plaster, kidney tray, antiseptic lotion, Bandaging role, Distilled water and Measuring glass

Site: Maximum tortuous area was selected for the Siravyadha.

Poorva Karma: Snigdha Yavagu was given to the patient, and after 1-hourAbhyanga with Moorchita Tila Talia and Nadi Swedana was given to the area in which Siravyadha was meant to be done.

Pradhana Karma: Tourniquet was tied above the site of Siravyadha and Raktamokshana was carried out using Vrihimukha Sastra (I.V. cannula of size 18 or butterfly cannula is used)

Paschat Karma: After the complete stoppage of bleeding loose bandage was applied. The food or diet, which was neither hot nor cold and was light, which could be easily digested, and that which stimulates the digestion was recommended. Advised the patient to have Ksheera along with Guda.

Group B: 30 patients were managed with Siravyadha. Site: Maximum tortuous area was selected for the Siravyadha.

Poorva Karma: Snigdha Yavagu was given to the patient, and after 1-hourAbhyanga with Moorchita Tila Thaila and Nadi Swedana was given to the area in Siravyadha and Raktamokshana was carried out using Vrihimukha Sastra.

Paschat Karma: After the complete stoppage of bleeding loose bandage was applied. The food or diet, which was neither hot nor cold and is light, which could easily digest, and that which stimulates the digestion was recommended. Advised the patient to have Ksheera along with Guda.

\section{Assessment Criteria:}

Assessment of the condition was done based on a detail proforma adopting different methods of scoring of subjective and objective parameters and was analysed statistically.

Following scoring pattern was adopted for the study to observe the changes in the signs and symptoms.

\section{Subjective Parameters:}
1) Pain
2) Itching sensation

\section{Objective Parameters}

1) Swelling

2) Pigmentation.

Effect of treatment was assessed statistically on the basis of gradation of both subjective and objective parameters before and after treatment.

Table 1: Showing Grading of Subjective and Objective parameters

\begin{tabular}{|c|c|c|c|c|c|c|c|}
\hline & Parameters/Grading & 0 & 1 & 2 & 3 & 4 & 5 \\
\hline 1 & $\begin{array}{l}\text { PAIN (McGill pain } \\
\text { score index) }\end{array}$ & None & Mild & Discomforting & Distressing & Horrible & Excruciating \\
\hline 2 & $\begin{array}{l}\text { Itching } \\
\text { Sensation }\end{array}$ & No itching & $\begin{array}{l}\text { Occasional } \\
\text { itching over } \\
\text { varicosal area }\end{array}$ & $\begin{array}{l}\text { Continuous } \\
\text { itching sensa- } \\
\text { tion }\end{array}$ & Nil & Nil & Nil \\
\hline
\end{tabular}




\begin{tabular}{|l|l|l|l|l|l|l|l|l|}
\hline 3 & Swelling & $\begin{array}{l}\text { No localized } \\
\text { swelling }\end{array}$ & $\begin{array}{l}\text { Swelling pre- } \\
\text { sent after long } \\
\text { exertion }\end{array}$ & $\begin{array}{l}\text { Swelling pre- } \\
\text { sent on standing } \\
\text { posture }\end{array}$ & $\begin{array}{l}\text { Swelling pre- } \\
\text { sent through- } \\
\text { out }\end{array}$ & Nil & Nil \\
\hline 4 & Pigmentation & $\begin{array}{l}\text { No discolora- } \\
\text { tion }\end{array}$ & $\begin{array}{l}\text { Reddish dis- } \\
\text { coloration }\end{array}$ & $\begin{array}{l}\text { Reddish blue } \\
\text { discoloration }\end{array}$ & $\begin{array}{l}\text { Total blackish Nil } \\
\text { discoloration } \\
\text { with scaling }\end{array}$ & Nil \\
\hline
\end{tabular}

Observations and Results: Higher incidence of Sirajagranthi was reported in age Group of 41-50 years. Out of 60 patients from group A and group B 53.33\% patients were belong to the age group of 41-50 years, $23.33 \%$ were belong to the age group of $51-60,18 \%$ were belong to $31-40$ and $5 \%$ belongs to $21-30$ age group. Out of 60 patients from group A and group B $34(56.67 \%)$ patients were male and $26(43.33 \%)$ are females. Out of 60 patients from group A and group B $68.33 \%$ are belongs to Hindu religion, $18.33 \%$ belongs to Muslim religion and $13.34 \%$ belongs to Christianity. Out of 60 patients from group A and group B $73.33 \%$ belongs to Middle class, $16.67 \%$ belongs to High class and $10 \%$ belongs to poor class. From the study, out of 60 patients from group A and group B 50\% patients belongs to strenuous category, $33 \%$ belongs to moderate category and $16.67 \%$ belongs to sedentary group. Out of 60 patients from group A and group B 93.33\% are married and 6.67\% are unmarried. Out of 60 patients from group $\mathrm{A}$ and group B 80\% have mixed diet and 20\% are vegetarian.
Out of 60 patients from group A and group B 75\% have regular bowel habit, $15 \%$ have irregular bowel habit and $10 \%$ have constipated bowel habit. Out of 60 patients from group A and group B, 33.33\% belongs to $71-80 \mathrm{~kg}, 28.33 \%$ belongs to $61-70 \mathrm{~kg}$, $18.33 \%$ belongs to $51-60 \mathrm{~kg}, 13.33 \%$ belongs to $41-$ $50 \mathrm{~kg}$ and $6.67 \%$ belongs to $81-90 \mathrm{~kg}$. From the study, out of 60 patients the duration of $95 \%$ cases have duration more than 1year and only $5 \%$ have the duration of below 1yr. Out of 60 patients from group A and group $\mathrm{B}$, in $86 \%$ cases varicose vein is present in both legs, $11 \%$ cases have varicose vein in right lower limb and $9 \%$ cases affected with varicose vein in left limb only.

Results: The observations procured on the assessment parameters of 60 patients before treatment (BT) and $28^{\text {th }}$ day (AT) in Group A and Group B were statistically analysed to determine the effect of the treatment Udwarthana followed by Siravyadha in Group A and Siravyadha in Group B.

Table 2: Effect on Group A (subjective and objective parameter)

\begin{tabular}{|l|l|l|l|l|l|l|l|l|}
\hline \multirow{2}{*}{ SYMPTOM } & \multicolumn{3}{|l|}{ MEAN SCORE } & $\%$ & SD $( \pm)$ & SE $( \pm)$ & Z Score & p- VALUE \\
\cline { 2 - 9 } & BT & AT & X=BT-AT & & & & & \\
\hline Pain & 2.6 & 0.9 & 1.7 & 85 & 0.6103 & 0.1114 & 4.2889 & $<0.05$ \\
\hline Itching sensation & 1.5 & 0.2 & 1.3 & 65 & 0.6513 & 0.1189 & 4.0792 & $<0.05$ \\
\hline Swelling & 2.06 & 0.6 & 1.4667 & 40 & 0.5713 & 0.1043 & 4.802 & $<0.05$ \\
\hline Pigmentation & 1.366 & 0.4 & 0.97 & 48.33 & 0.585 & 0.0895 & 4.62 & $<0.05$ \\
\hline
\end{tabular}

Table 3: Effect on Group B (subjective and objective parameter)

\begin{tabular}{|l|l|l|l|l|l|l|l|l|}
\hline \multirow{2}{*}{ SYMPTOM } & \multicolumn{3}{|l|}{ MEAN SCORE } & $\%$ & SD $( \pm)$ & SE $( \pm)$ & Z Score & p- VALUE \\
\cline { 2 - 10 } & BT & AT & X=BT-AT & & & & & \\
\hline Pain & 3 & 1.9 & 1.1 & 55 & 0.5307 & 0.0969 & 4.2889 & $<0.05$ \\
\hline Itching sensation & 1.46 & 0.8 & 0.6667 & 33.33 & 0.5467 & 0.0998 & 4.08 & $<0.05$ \\
\hline Swelling & 1.9 & 1.26 & 0.6333 & 31.66 & 0.4901 & 0.0895 & 4.802 & $<0.05$ \\
\hline Pigmentation & 1.76 & 0.933 & 0.8333 & 41.66 & & Pigmentation & 1.76 & 0.933 \\
\hline
\end{tabular}


Table 4: Comparative Effects of Treatment between Two Groups

\begin{tabular}{|l|l|l|l|l|l|}
\hline Signs and Symptoms & Group A (Mean Score) & $\begin{array}{l}\text { Group B } \\
\text { (Mean Score) }\end{array}$ & Z-Value of Mann Whitney & U Value & P Value \\
\hline Pain & 1.7 & 1.1 & 3.119 & 238.5 & $<0.05$ \\
\hline Itching Sensation & 1.3 & 0.6667 & 3.119 & 233.5 & $<0.05$ \\
\hline Swelling & 1.4667 & 0.6333 & 4.317 & 157.5 & $<0.05$ \\
\hline Pigmentation & 0.97 & 0.8333 & 4.72 & 212.5 & $=0.05$ \\
\hline
\end{tabular}

Table 5: Comparative Percentage of Relief between Group- A \& Group- B

\begin{tabular}{|l|l|l|l|l|}
\hline \multirow{2}{*}{ Signs \& Symptoms } & Mean Difference & \multicolumn{2}{l|}{ Percentage Relief \% } \\
\cline { 2 - 4 } & Group A & Group B & Group A & Group B \\
\hline Pain & 1.7 & 1.1 & 85 & 55 \\
\hline Itching Sensation & 1.3 & 0.6667 & 65 & 33.33 \\
\hline Swelling & 1.4667 & 0.6333 & 40 & 31.66 \\
\hline Pigmentation & 0.97 & 0.8333 & 48.33 & 41.66 \\
\hline
\end{tabular}

Comparative analysis of the overall effect of the treatments in both the groups was done by statistically with Mann Whitney test. The test shows that the treatment is significant in Group A when compared to Group B. Group A overall result is $52.915 \%$ and Group B overall result is $41.245 \%$.

\section{DISCUSSION}

\section{Discussion on Review of Literature}

Sirajagranthi is one among the Granthi Rogas which is explained in the classics, denotes a pathological condition characterised by an elevated, quick developing and round swelling of veins, which are non- pulsating and painless. It would have given a clear-cut picture of the varicose vein if there is a clear description of its related anatomy and pathology.

So, the above-mentioned symptoms, shows that Sirajagranthi can be correlated to varicose vein, though the concept of Siragata Vata, Vatasonita, Avarana concepts etc. can be borrowed for the management due to the involvement of Vata and Rakta in its Samprapti.

The disease Sirajagranthi is described in the context of Granthi-Apachi-Arbuda-Galaganda chapter by Sushrutha and Vagbhata.

Table 6: Correlation between Sirajagranthi and Varicose vein

\begin{tabular}{|l|l|l|}
\hline & Sirajagranthi & Varicose vein \\
\hline Involved structure & Sira & Veins \\
\hline Symptoms & Sampeedya, Nisphuram, Nirujam & Diffuse dull aching pain \\
\hline Signs & Samkochya, Vrutta, Unnatha, Vakrikritya, Shopham & Dilated, elongated, and tortuous veins \\
\hline
\end{tabular}

The pathology of varicose veins are, under normal conditions the blood from the superficial venous system is passed to the deep veins through the competent perforators and from deep veins the blood is pumped up to the heart by the muscle pump, competent valve and negative intrathoracic pressure. But if this mechanism breaks down, either due to destruction of valves of the deep veins, or of the superficial venous system, the blood becomes stagnated in the superficial veins which become the pray of high pressure leaks and thus becomes distended and tortuous and become varicose veins.

The main aim of the treatment in contemporary science is to strengthen the veins walls and valves and muscles, to achieve good venous flow from the lower extremities and to avoid the complications of varicose veins. The treatment explained in the classics serves the above aim of the treatment. 


\section{Discussion on Results}

Overall effect of treatment: In Group A, the effect of Siravyadha done after Udwarthana as Purvakarma in signs and symptoms of Sirajagranthi as assessed on before and after treatment showed better improvement in clinical conditions and which was statistically more significant changes than group B.

Effect on Pain: In group A, out of 30 patients, the mean score of pain before treatment was 2.6 which was reduced to 0.9 on 28th day after Udwarthana with Siravyadha with $85 \%$ improvement. This revealed a statistically more significant effect of Siravyadha done after Udwarthana on Shoola at $\mathrm{p}<0.05$

As Sirajagranthi is a result of vitiated Vata along with stagnation of vitiated Rakta causes pain in legs. After the treatment of Udwarthana along with Siravyadha the relief of pain may be due to the bringing back of Vata into normalcy by Udwarthana and Nirharana of the Sesha Dosha along with Dushta Rakta by Siravyadha.

The pain is caused by the tortuous veins which further stimulates release of neurotransmitter ( $\mathrm{P}$ substance) which gets collected in the smooth muscles of the blood vessels. And also, there is venous hypertension which results in stretching of veins causing the pain. As Udwarthana followed by Siravyadha tones the muscles, removes the stasis due to the removal of stagnant vitiated blood which in turn washes away the $P$ substance and reduces the intravascular pressure.

In Group B, out of 30 patients, the mean score of pain before treatment was 3 which was reduced to 1.9 on 28th day after Siravyadha with 55\% improvement. This revealed a statistically significant effect of Siravyadha on pain at $\mathrm{p}<0.05$. Vitiated Vata is a factor for causing pain because it causes Sampeedana of veins. After Raktamokshana, relief of pain may be due to Nirharana of the Vata along with Dushta Rakta.

\section{Effect on Itching Sensation}

In Group A, out of 30 patients, the mean score of itching sensation before treatment was 1.5 which was reduced to 0.2 on $28^{\text {th }}$ day after Udwarthana with Siravyadha with $65 \%$ improvement. This revealed a statistically more significant effect of Siravyadha done after Udwarthana on itching sensation $\mathrm{p}<0.05$. As due to stasis of blood in varicose veins, Extravasation and break down of R.B.C in the lower part of the leg stimulates histamine to deposit at the site which causes vasodilatation and vascular permeability and itching. As there is the involvement of vitiated Rakta, Vikruta Kapha and vitiation of Mamsa and Medas, by Udwarthana the stasis of blood can be removed from the site and it also stimulates the pumping action of veins by giving strength to muscles which further avoid the breakdown of RBC and results in reduction in itching sensation and after Siravyadha it removes the stasis due to the removal of remaining stagnant vitiated blood which in turn washes away the stagnated blood and histamine.

In Group B, out of 30 patients, the mean score of itching sensation before treatment was 1.46 which was reduced to .8 on 28th day after Siravyadha with $33 \%$ improvement. This revealed a statistically significant effect of Siravyadha on itching sensation at $\mathrm{p}<0.05$. Siravyadha acts on itching sensation by removing the stagnated blood from the Sira that removes the Sanga from the Srotas.

\section{Effect on Swelling}

In Group A, out of 30 patients, the mean score of Swelling before treatment was 2.06 which was reduced to 0.6 on $28^{\text {th }}$ day after Udwarthana with Siravyadha with $40 \%$ improvement. This revealed a statistically more significant effect of Siravyadha done after Udwarthana on Swelling $\mathrm{p}<0.05$. Swelling is due to venous outlet obstruction which increases capillary hydrostatic pressure and cause collection of tissue fluid. Due to Vatakaphahara and Siramukhavivechana property of Udwarthana along with Tridoshahara and Shothahara properties of drugs results in relieving of intravascular pressure which further results in subside the swelling.

In Group B, out of 30 patients, the mean score of swelling before treatment was 1.9 which was reduced to .1 .26 on 28 th day after Siravyadha with $31 \%$ improvement. This revealed a statistically significant effect of Siravyadha on swelling at $\mathrm{p}<0.05$. Siravyadha helps to relieve the intravascular pressure and helps to subside the swelling.

Effect on Pigmentation 
In Group A, out of 30 patients, the mean score of Pigmentationbefore treatment was 1.36 which was reduced to 0.4 on $28^{\text {th }}$ day after Udwarthana with $\mathrm{Si}$ ravyadha with $48.33 \%$ improvement. This revealed a statistically more significant effect of Siravyadha done after Udwarthana on Pigmentation $\mathrm{p}<0.05$. Discoloration is mainly seen in the lower part of the leg due to hemosiderin deposition from breakdown of $\mathrm{RBC}$ which have come off the thin walled veins. Due to Vranahara, Raktaprasadana property of drugs and due to overall effect of Udwarthana with Siravyadha, the stagnated blood get flow out from the site results in the entry of fresh blood and supplement of nutrients results in reduction of pigmentation.

In Group B, out of 30 patients, the mean score of pigmentation before treatment was 1.76 which was reduced to.93 on 28th day after Siravyadha with $41.6 \%$ improvement. By Siravyadha, due to removal of stagnated blood i.e. dead RBC along with iron in the form of hemosiderin from the veins occurs which helps to reduce the pigmentation.

\section{a) Discussion on comparative Percentage relief of Group A and Group B \\ $>$ Pain - In Group A 85\% of relief and Group B 55\% relief was observed.}

$>$ Itching Sensation - In Group A 65\% of relief and Group B 33.3\% relief was observed

> Swelling - In Group A 40\% of relief and Group B $31.6 \%$ relief was observed

$>$ Pigmentation - In Group A $48.3 \%$ of relief and Group B 41.6\% relief was observed

Thus, Siravyadha done after Udwarthana showed more significant results in the symptoms like pain, itching sensation, swelling and pigmentation.

Thus, the total effect of Siravyadha done after $U d$ warthana was better than Siravyadha done without Udwarthana.

\section{Mode of Action of The Procedures}

\section{A) Mode of action of Siravyadha}

Raktamokshana invariably results in immediate repair when compared to other therapeutic procedures which takes longer duration to reduce the symptoms.

"Siravyadham Ardha Chikitsa Shalyatantre Prakirtitah"
Siravyadha is considered as Ardha Chikitsa or it is considered as the complete treatment in some of the surgical diseases. The role and importance of Rakta in the genesis, manifestation and progress of the disease are not being given due emphasis resulting in overall poor rating over the process Raktamokshana as a radical treatment. There is considerable involvement of Rakta and its Upadhatu-s in the genesis, manifestation and progress of condition with respect to varicose veins. Siravyadha is one such kind of radical treatment which helps to removes the Dushtarakta.

As Siravyadha is a type of Shastravacharaniya Raktamokshana procedure, two Shastra have been mentioned in classics for Vyadhana purpose. One is Vrihimukha Shastra and the other is Kutharika Shastra, former to be used in Mamsala Pradesa and later in Asthi Pradesa. In the present study Siravyadha was carried out using Kutharika Shastra. By using VrihiMukha large amount of vitiated blood can be removed from the maximum tortuous area which gives more symptomatic relief. Siravyadha is a simple procedure and can be practiced even in OPD levels.

\section{Probable mode of action of Siravyadha}

- In the disease Sirajagranthi, the main vitiated factors are Vata and Rakta. By doing Siravyadha, the stagnant vitiated Rakta gets drained out which will help to retain the Chala Guna of Vata.

- By removing the stagnant vitiated blood that had caused Sanga, Siravyadha reduces intravascular pressure and volume hence relieving Shoola and Shotha.

- Since the stagnant blood is drained out, the breakage of RBC gets reduced which in turn reduce the pigmentation and itching over the part.

- Vitiated Vata in Sira causes Siraakunchana (dilatation of the veins) and stimulate release of substance $\mathrm{P}$ which gets collected in smooth muscle of blood vessels causing pain.

- After doing Siravyadha, this is removed from the blood thus causing relief in pain.

- Vata Shamana is also done by Snigdha Ahara which is given at the time of Paschat Karma.

There is considerable role of Rakta and its Upadhatu in the genesis, manifestation and progress of the con- 
dition with respect to varicose veins. Siravyadha is one such radical treatment especially concerned with Dushta Rakta Nirharana (the macroscopic removal of morbid blood from unwanted contexts or situations.) Patho-physiological studies suggests that in case of a considerable blood loss $(>100 \mathrm{ml})$, the immediate haemodilution stimulates or triggers a host of beneficial physiological mechanisms making the body alert and adaptive to take care of various systemic challenges present and those cross the body in the near future.

Shonitha Kleda is one among the Pitta Nanatmaja Vikara here Kleda refers to multiple intermediate metabolites particle which embedded in Rakta which triggers skin changes, oedema hence Raktamokshana by Siravyadha is an attempt to reduce the Kleda in Rakta. Even more "Raktam hi Amlatam hi thatha cha ruk" - amlata in Rakta (inflammatory markers, intermediate metabolites, Substance P) is responsible for Ruk that is all type of Pain. Hence forth Raktamokshana by Siravyadha is instrumental by relieving symptom like Ruja.

In general, the various probable mechanisms are going to change in the body by bloodletting, such as local blood supply is improved, local metabolism is improved, local drainage system is improved, fresh RBCs are produced which are active.

If the above conditions are treated earlier, then various steps of complications can be stopped, otherwise severe anoxia in the lower part of the leg and surrounding tissue can lead to chronic venous ulceration. Recurrent varicose veins are veins which have become varicose after the previous treatment, which had once become 'normal' after the treatment. This occurs when all the visible varicosities were treated but the underlying abnormality was not corrected; the remaining 'normal' veins abnormal pressure and subsequently dilate.

The mechanisms of releasing hormones sympathetic nerve functions etc. are triggered which helps to stimulate the bone marrow immune related $\mathrm{T}$ lymphocytes. Raktamokshana invariably results in immediate repair when compare to other therapeutic procedures that take longer periods for the relief of Symptoms.

\section{Discussion on probable mode of action of Udvar-} tana along with Siravyadha

Udvartana is one of the Panchakarma therapies which differ from Abhyanga in its direction of application and pressure during the procedure. It is a simple and affordable procedure with no harmful effects and done with Kolakulathadichurna which contains drugs like kola, Kulathasuradaru, Suradaru, Rasna etc.all these drugs possessing qualities like Tridoshahara (mainly kaphavatahara), vranahara, Kandughna, Amaharatwa, Siramukhavivechana etc. It possesses Shoshana (absorption) and Kapha-Medohara (alleviation of vitiated Kapha and Meda) properties. it helps to bring back the Vikrutha Vayu to its normalcy.

Seven days course of Udvartana was given to the patients of group A for about 20-minute duration in supine and prone position in Pratiloma direction. As mentioned in Samprapti of Sirajagranthi the Vatakaphadosa involved along with vitiation of Raktha, Mamsa and Medodhathu. So, while doing rubbing it opens the minute channels and improves blood as well as lymphatic circulation result in relief of blood stasis and carries away morbid products in the system. The production of heat due to Udvartana promotes local circulation and metabolic activities and opens the pores of the skin to permit transfer of medicaments and nutrients towards needed sites and elimination of vitiated Doshas and Malas through skin and perspiration. It provides a platform for further procedures. After 7 days of Udvartana patient was undergone with Siravyadha procedure.

The probable mode of action can be hypothesized as follows

The medicated powder is rubbed over body in the opposite direction of hair root. Rubbing may help in the absorption of effusions, relief of blood stasis and carries away the morbid products in the system. The pressure helps the contents of the blood vessels move towards the heart, if applied strongly and quickly, it has a stimulating effect. It increases nutrition in tissues, removes fatigue, carries away the increased products of combustion. The skin as well as the struc- 
tures which lie beneath it is affected by massage. The stored amount of blood may be brought in the systemic circulation instead of them remaining dormant in the stored system.

Udvartana has Kapha-Medavilayana property. To enhance the Medovilayana property, Katu-Tikta rasa (pungent-bitter); Ushnavirya; Laghu Ruksha-Tikshna Gunadravyas are present. Twakasthaagni gets stimulated, this leads to absorption and digestion of the drug and further does Pravilayana of Medo Dhatu (liquefaction of subcutaneous fat) below skin may occur.

$\checkmark \quad$ It has got great influence on the muscles. It gives them a mechanical stimulation causing them to contract.

$\checkmark$ It increases circulation mainly in the veins. The alternate pressure and relaxation bring fresh blood to the part.

$\checkmark \quad$ It improves the nutrition of the particular area.

$\checkmark$ It raises temperature locally.

$\checkmark \quad$ It increases elimination of waste products.

$\checkmark$ It increases secretion and absorption.

$\checkmark$ It improves the condition of the nervous system by stimulating the cutaneous nerve endings.

$\checkmark \quad$ It influences the general metabolism when applied on large areas.

$\checkmark$ Helps to breakdown thickening and adhesions in sub-acute and chronic conditions.

Also helps in the reabsorption of inflammatory products and absorption of fat in fatty tissues

\section{CONCLUSION}

In this clinical study, both Group A and Group B showed significant results in all attributes of Sirajagranthi

On comparison there is statistically significant difference between the two groups in pain (Group A 85\%), itching sensation (Group A 65\%), swelling (Group A $40 \%$ ) and pigmentation (Group A 48\%) of Sirajagranthi.

Therefore, on the basis of the observations from the present study, it may be concluded that the total effect of Siravyadha after Udvartana was better than Siravyadha done without Udvartana in the management of
Sirajagranthi. On comparison there is statistically significant difference between the two groups in pain (Group A 85\%), itching sensation (Group A 65\%), swelling (Group A 40\%) and pigmentation (Group A $48 \%$ ) of Sirajagranthi. Siravyadha done after Udvartana showed more results in main attributes like pain, itching sensation and pigmentation.

As from the study, the null hypothesis $\mathrm{HO}$ is rejected and the alternate hypothesis H1 is accepted i.e. H1There is significant effect of Udvartana with Siravyadha in Sirajagranthi (varicose vein).

\section{REFERENCES}

1. http://en.wikipedia.org/wiki/varicose vein_in_India.

2. 'Aryavaidyan'- A quarterly jounal of the Arya Vaidyasala - Kottakal, Vol XXVII, No.4 MayJuly,2014.

3. Dr.Somen Das. A Concise Textbook of Surgery, 4th edition. Calcutta, 2006, pg no: 202-210.

4. Acharya Vagbhata, Ashtangahrudaya with commentaries of Sarvangasundari Sanskrit commentary by Arunadatta edited by PanditHarisadashivashastrichoukambasurabharathiprakashan, Varanasi2010, Uttarasthana 30/6 Page no-810.

5. A.S, U Ch: $34 / 11$; Ch: 35/7; Su: Ch: 36/3,4.

6. S.S Ni Ch: 11/8-9; Ch :1/26-27

7. Acharya vagbhata,Astangasamgraha text with English translation by $\operatorname{Dr} \mathrm{P}$ Srinivas rao published by chaukambakrishnadasacademy,Varanasi,2007, vol 1 sutrasthana.

8. Acharya Susrutha: Susrutha Samhita with Nibandhasangraha Commentary of Dalhanacharya and NyayachandrikaPanchika of Gayadasa edited by YadavjiTrikamji, Published by ChaukambaOrientalia, Varanasi-2009, ChikitsaSthanaCh 24/56-, pgno:-489.

\section{Source of Support: Nil \\ Conflict of Interest: None Declared}

How to cite this URL: Neethu Dev et al: A Comparative Clinical Study On The Effectiveness Of Udvartana With Siravyadha In The Management Of Sirajagranthi (Varicose Vein). International Ayurvedic Medical Journal \{online\} 2020 \{cited November, 2020\} Available from: http://www.iamj.in/posts/images/upload/5021 5030.pdf 